\title{
Língua, memória e identidade. Considerações metodológicas sobre histórias de vida de migrantes bilíngues
}

\author{
Méri Frotscher*
}

Na obra $A$ arte da conversação, o historiador Peter Burke (1995), ao apontar a existência de uma lacuna entre as disciplinas da história, da linguística e da sociologia, argumenta em prol da incorporação da linguagem à história social e cultural. Para o autor, a linguagem é parte da cultura e da vida cotidiana e seu estudo é "um meio para a melhor compreensão das fontes orais e escritas pela via da consciência de suas convenções lingüísticas” (Burke, 1995, p. 10). Burke (1995, p. 9-19) pleiteia uma abordagem que dê uma dimensão social à história da linguagem, pois a linguagem, tanto a escrita como a oral, longe de ser autônoma e independente, se constrói num processo de interação social.

Essas considerações nos levaram a refletir sobre as interações sociais envolvidas na própria produção das fontes históricas, em especial as orais. Pois se os documentos são sempre escritos levando-se em conta o destinatário, as fontes orais são sempre constituídas num processo dialógico com o entrevistador. Nosso argumento, neste artigo, é o de que o caráter dialógico da produção das fontes orais interfere não apenas no conteúdo da narrativa,

* Professora dos cursos de graduação e mestrado em História da Universidade Estadual do Oeste do Paraná (Unioeste). 
mas também na sua forma, na linguagem empregada, incluindo aqui a(s) língua(s) e suas variações. ${ }^{1}$

Se a história oral nos diz menos sobre fatos e mais sobre os significados que os entrevistados constroem e atribuem ao passado, como sugere Alessandro Portelli (1996, p. 60), e se a linguagem através da qual são dados sentidos às coisas não é algo dado, reflexo da realidade, devemos levar em conta também os trabalhos da linguagem na produção dos significados. E, nesse aspecto, como ressalta Burke (1995, p. 17), a questão "quem fala qual língua para quem e quando" também significa.

Neste artigo trataremos, especificamente, dos significados do uso desta ou daquela língua, ou de ambas, em entrevistas de história de vida com pessoas bilíngues que vivenciaram migrações entre Brasil e Alemanha na primeira metade do século XX. ${ }^{2}$ Tentaremos mostrar que incorporar à análise reflexões sobre o uso de uma ou mais língua numa situação de entrevista pode tanto aprofundar a interpretação dos relatos orais como também possibilitar discutir questões metodológicas envolvidas na sua própria produção.

O bilinguismo, característico de nossos entrevistados e expressos nos relatos orais produzidos, nos instiga também a refletir sobre as relações entre língua, memória e identidade. Entendemos que a questão do emprego (consciente ou não) de uma outra língua, ou ambas, ou também de dialetos em situações de entrevista é uma questão instigante a ser pensada, sobretudo quando o interesse do pesquisador se volta para a construção de subjetividades e expressão de identidades em contextos multiculturais ou em movimentos migratórios internacionais onde ocorrem intersecções linguísticas.

Essas inter-relações serão discutidas a partir de três entrevistas realizadas no Brasil com pessoas que viveram experiências marcantes de migração

1 Entendemos a língua não como algo homogêneo, pois além de existirem variações de uma língua conforme o tempo e o espaço, existem variações numa mesma comunidade linguística. Estas possibilidades diferentes de se realizar a mesma língua são chamadas, na sociolinguística, de "variações linguísticas"(Alkmim, 2003).

2 Consideramos aqui tanto os entrevistados caracterizados por um "bilinguismo equilibrado", nos casos em que os níveis de competência são relativamente equivalentes, como por um "bilinguismo dominante", nos casos em que as competências são assimétricas. Sobre isso e as distintas definições sobre capacidades bilíngues e abordagens sobre bilinguismo, ver Serrani-Infante (1998, p. 231-264). 
e de guerra. Os entrevistados são imigrantes alemães ou seus filhos que chegaram ao Brasil durante os anos 1920 e se dirigiram à Alemanha nacionalsocialista, principalmente no final dos anos 1930. Este constituiu um fluxo numericamente pequeno, se comparado ao número de alemães no Brasil à época, mas significativo em diversos aspectos. Dois dos entrevistados citados foram "repatriados"3 ao Brasil logo após a II Guerra Mundial, por intermédio da Missão Militar Brasileira que se encarregou de cadastrar os cidadãos brasileiros que estavam na Alemanha ocupada logo após a guerra e intermediar a "repatriação" dos desejosos em retornar.

Aos entrevistados foi dada a possibilidade de escolher a língua principal da entrevista. Mas eles, em geral, não utilizaram somente uma das línguas nas entrevistas. Das três a serem mencionadas, duas foram concedidas principalmente em língua alemã, enquanto que a terceira principalmente em língua portuguesa. Os três entrevistados procederam alternância linguística, o chamado code-switching, quando há alternância de um ou mais línguas ou dialetos numa conversa.

Este artigo ressalta a importância da reflexão sobre as alternâncias de línguas numa situação de entrevista. Nosso intento também é discutir como esses entrevistados bilíngues narram suas vivências durante o momento da entrevista, através de que língua(s) e quais os significados possíveis dessas utilizações e alternâncias de língua e, ainda, como isso pode estar ligado a diferentes elementos.

3 Utilizamos "repatriação" entre aspas, pois nos referimos a um termo utilizado à época pelas autoridades brasileiras e pelo comando aliado que administrava a Alemanha ocupada. E também porque muitos dos que foram "repatriados" depois da II Guerra Mundial haviam se dirigido à Alemanha anteriormente como se ela fosse sua "pátria". A maioria dos entrevistados se refere à sua volta ao Brasil após a guerra como um mero retorno, não como uma repatriação.

4 O projeto de pesquisa "Memórias da guerra e do nazismo: a repatriação de cidadãos brasileiros da Alemanha após a II Guerra Mundial”, desenvolvido desde 2009, objetivou produzir entrevistas de história de vida com cidadãos brasileiros que se dirigiram à Alemanha durante o III Reich e retornaram ao Brasil entre 1947 e 1949 com a intermediação do governo brasileiro, assim como com parentes alemães que os acompanharam. Através do projeto também foi realizada pesquisa documental no acervo do Itamaraty, no Rio de Janeiro e em diversos arquivos na Alemanha, com o objetivo de investigar tanto a migração para a Alemanha durante o nazismo como a "repatriação" após a guerra. As pesquisas naquele país foram viabilizadas por uma Bolsa de Estágio Pós-Doutoral da Capes (Proc. BEX 1236/10-5). 


\section{Os sentidos da língua}

Comecemos por um caso narrado por uma senhora, a qual chamaremos de Ruth Vogt, filha de um pastor luterano nascida no sul do Brasil no início dos anos 1920. Em 1938, ela acompanhou a família em viagem à Alemanha, quando resolveu permanecer sozinha em Berlim para estudar música, enquanto a família retornou ao Brasil. Os estudos foram possibilitados por uma bolsa de estudos da VDA - Volksbund für das Deutschtum im Ausland - uma entidade não governamental, mas então cooptada pelo governo nacional-socialista, como todas as entidades similares então existentes àquela época na Alemanha. A VDA visava manter o Deutschtum (germanidade) ${ }^{5}$ entre os descendentes de alemães espalhados no mundo e por isso trabalhava em conjunto também com a Igreja Evangélica de Confissão Luterana no Brasil, a qual também primava pela manutenção da língua e da cultura alemãs entre os imigrantes e seus descendentes. $\mathrm{O}$ irromper da guerra, em setembro de 1939, cortou-lhe os canais de comunicação com a família e tornou impossível seu planejado retorno ao Brasil.

$\mathrm{Na}$ Alemanha, Ruth foi logo incorporada à sociedade e economia nacional. Após os estudos trabalhou como professora de música para alemães na Polônia ocupada pelas tropas nazistas. Sem poder se comunicar com a família no Brasil, casou-se em 1942 com um colega de estudos, o qual durante a guerra serviu como oficial da Luftwaffe. Ele morreu na próxima missão da qual foi incumbido, após o casamento, quando Ruth já estava grávida. Após o nascimento do filho, Ruth viveu então com seu bebê numa pequena cidade da Turíngia. Para ela, a guerra terminou com a ocupação da cidade pelas tropas norte-americanas.

Sessenta e cinco anos depois, na entrevista de história de vida concedida em alemão, língua através da qual ainda hoje conversa com os filhos, ela comenta sobre seu primeiro encontro com os soldados norte-americanos:

Und dann klopft es schon an unsere Tür, weist Du, das war so ein amerikanischer Soldat, so ein Negerjung, war ein Neger: "Have you paper?” [?].

5 O termo Deutschtum, em geral traduzido simplesmente como "germanidade", remete a um conjunto de traços que serviam para definir a identidade alemã, tais como a ascendência alemã, o uso da língua alemã como língua materna, o compartilhamento de costumes e tradições alemães. 
Und dann hab ich mich gleich als Südamerikanerin [?], nicht, und da hab ich zum Glück einen ganz kleinen Ausweis - ich hatte ja, ich war ja schon Deutsche - von der Vacina hier in [Name der Stadt], bevor ich weg [ging] - da war dann die brasilianische Fahne drauf, e ele caiu nessa! (Ruth Vogt, entrevista em 10/02/2010, grifo meu). ${ }^{6}$

Naquele momento de perigo, posicionar-se identitariamente como sulamericana significava, sobretudo, afirmar-se como "não alemã". Era uma tática para se preservar diante das esperadas retaliações aos alemães, representados como os inimigos pelos aliados. Ao ressaltar sua procedência americana, teria convencido com astúcia o soldado ao mostrar sua carteirinha de vacinação brasileira. Lembramos aqui de Stuart Hall (1996), quando afirma que o que falamos está sempre "em contexto", posicionado.?

A afirmação de que teria se apresentado como sul-americana pode ter sido influência do fato de ter vivido após a guerra com seu filho num campo de displaced persons (deslocados de guerra), cuja boa parte era de origem sulamericana. ${ }^{8}$ Além do momento sobre o qual relatou e do momento presente, quando concedeu a entrevista, pode ter tido influência outra temporalidade na sua autoidentificação enquanto sul-americana: a vivida em 1946/1947 naquele campo. Isso demonstra o funcionamento da memória autobiográfica. As histórias de vida são construídas não apenas com base em fatos vividos no momento sobre o qual se relata, mas também com base em experiências

6 "E então eles já bateram à nossa porta, sabe, era um soldado americano, um negrinho, ele era negro: 'Você tem documentos?' [incompreensível]. E então eu logo me apresentei como sul-americana [incompreensível], né? E eu por sorte tinha um documento de identificação bem pequeno - eu já tinha, eu já era alemã - da vacina aqui de [nome da cidade], antes de eu partir - e ali estava a bandeira brasileira em cima, e ele caiu nessa!"

7 A noção de posicionamento identitário nos permite perceber o caráter fluido e instável das identidades individuais, sempre em processo e constituída interna e não externamente à representação (Hall, 1996, p. 68).

8 Na época da "repatriação" da primeira leva de cidadãos brasileiros, na qual estava a entrevistada e seu filho, artigo publicado no The New York Times relata a presença de 2.097 latino-americanos em campos de deslocados de guerra na zona americana da Alemanha. O mesmo artigo critica esse fato, argumentando que eles não poderiam ser considerados deslocados de guerra, pois não haviam vindo à Alemanha contra sua vontade. Esta seria a condição para se considerar alguém um displaced person. Cf. Latinamericans lose aid abroad. The New York Times, 22.2.1947. Transcrição do artigo na Pasta 3/174-1/11 (Proveniência OMGUS PW\& DP Div). Instituto de História Contemporânea, Munique. 
vividas depois ou, como demonstra o psicólogo social Harald Welzer (2002, p. 12), estudioso sobre o funcionamento da memória, até mesmo com base em fontes bem diferentes, como conversas, livros e filmes, devido ao caráter comunicativo da memória.

Como Ruth relatou, foi a bandeira brasileira na carteira de vacinação que teria servido para identificá-la como brasileira. Talvez tenha, de fato, se identificado como brasileira, não como sul-americana. Tendo se apresentado desta ou daquela forma, o que fica claro é que seu principal propósito naquele momento foi realçar uma procedência não alemã. Nesse sentido, declarar uma identidade brasileira ou sul-americana ao soldado norte-americano significava também (e principalmente) marcar uma identidade não alemã.

Esse episódio narrado permite apreender, de uma maneira muito sugestiva, como se instituem identidades e, assim, também diferenças, por meio de atos de fala (Silva, 2005, p. 77). Isso porque tanto a identidade como a diferença se constroem por meio da linguagem. Vista sob essa perspectiva, a identidade brasileira, como aponta Tomaz Tadeu da Silva (2005, p. 76-80), contém em si mesma o traço do outro, da diferença, pois o signo não carrega consigo apenas o traço daquilo que ele substitui, mas também daquilo que ele não é.

O posicionamento identitário de Ruth durante o encontro com o soldado constituiu uma tática que lhe garantiu um melhor tratamento, se comparado ao dado aos demais alemães que moravam na mesma edificação, naquele momento de contato com o inimigo de guerra. Segundo ela relata na sequência da entrevista, enquanto os outros alemães tiveram que dormir no chão naquela noite, pois os soldados norte-americanos haviam tomado suas camas, ela e o bebê puderam continuar a dormir em seus leitos. Depois, todas as demais famílias teriam tido que deixar as casas daquela rua, a melhor da cidade, para ali morarem os oficiais norte-americanos. A ela e ao filho, contudo, teria sido permitido permanecer e, inclusive, receber todos os dias pão, algo muito importante naquele período de fome.

Como se pode apreender, determinados papéis de gênero comumente associados às mulheres, como o da maternidade e o de amamentar o filho, estiveram em jogo naquele momento e foram reconhecidos por aqueles soldados. Ser mãe de um bebê e reconhecida enquanto cidadã brasileira pelo princípio do jus solis lhe trouxe também a possibilidade de ser incluída na primeira leva de "repatriados", no início de 1947, quando finalmente retornou 
ao Brasil a bordo do navio Santarém. ${ }^{9}$ Mulheres, crianças e pessoas idosas foram priorizadas pelo governo brasileiro.

A leitura do trecho anteriormente citado permite perceber que a entrevistada se utiliza de três línguas para contar o episódio, realizando shifts linguísticos em dois momentos. Se citássemos apenas a tradução e não o trecho original da entrevista seria impossível percebê-los. Os shifts, entretanto, têm seus significados dentro da narrativa oral e merecem atenção, pois lidamos com entrevistas de pessoas que expressam bilinguismo na conversa com a interlocutora por conta das possibilidades abertas para isso. No caso de Ruth, além do alemão e do português falados fluentemente por ela, no trecho citado emerge outra língua, a inglesa, quando ela tenta reconstituir a cena em que o soldado norte-americano a interpela. Assim, ela também retrata um novo período da história cotidiana dos alemães, os quais passaram a conviver com as tropas de ocupação. Para tanto, no meio da narrativa, a entrevistada fez uma performance. A entonação utilizada ao falar "Have you paper?" tem o objetivo de dramatizar aquele encontro com o soldado. A tentativa de reprodução da fala de um terceiro na sua própria língua cumpre a função de melhor encenar o encontro com o soldado naquele momento de apreensão. O erro gramatical na frase em inglês - o soldado certamente não falou daquela maneira, ao tentar reproduzir a frase em inglês a entrevistada usou a estrutura gramatical do alemão - evidencia a falta de domínio daquela língua pela entrevistada e os trabalhos da memória referente a uma cena vivida há tantas décadas.

Noutro momento do trecho citado, a entrevistada utiliza outro shift linguístico, dessa vez para a língua portuguesa. Ao perceber a curiosidade da interlocutora, também oriunda de um contexto cultural teuto-brasileiro com a qual, por isso, imaginava compartilhar códigos culturais e linguísticos - usa uma expressão em português - "e ele caiu nessa!" - para expressar o sucesso de sua tática. Essa expressão em português é o ponto alto da estória, ${ }^{10}$ quando ela parece querer ressaltar certa esperteza frente ao ex-inimigo e sua suposta ingenuidade, muito embora fosse ele o representante do exército

9 O subchefe daquela missão descreve a atuação da Missão Militar Brasileira na Alemanha entre 1945 e 1949 em dois momentos e contextos nacionais diferentes. Em 1951, publica no Brasil um livro pela editora do Exército (Tavares, 1951) e, em 1990, na Alemanha, um artigo em revista bilíngue voltada para as relações Brasil/Alemanha (Tavares, 1990).

10 Uso aqui o termo "estória" no sentido de anedota, ou seja, um relato sucinto de um fato curioso ou jocoso. 
vencedor. Esse posicionamento é expresso na própria caracterização de conotação diminutiva e pejorativa do soldado ("ein Negerjung, war ein Neger" "um negrinho, era um negro"). Como se apreende na leitura do trecho, ela vê a necessidade de informar que o soldado era negro, usando a palavra Neger, difundida na época. ${ }^{11}$

A passagem em que Ruth relata ter se apresentado como não alemã traduz também a ideia do "jeitinho" (brasileiro?)12 usado por ela naquele momento de derrota da Alemanha e ocupação norte-americana. $\mathrm{O}$ ato de mostrar a carteirinha pessoal constituiu uma tática, no sentido do qual fala Michel de Certeau (2005), pois ela se aproveitou de brechas surgidas no momento para sobreviver num contexto político e militar em que as relações de força na Europa haviam se invertido, ou seja, em que ser alemão era estar do lado derrotado. Segundo Certeau (2005, p. 100-101), "a tática é a arte do fraco": ela não teria a autonomia da estratégia, pois ela deve jogar com o terreno que lhe é imposto.

Exatamente naquele momento de virada da história contemporânea ocidental, Ruth se identificou e foi reconhecida como brasileira, o que os outros entrevistados só fizeram mais tarde, quando souberam da possibilidade de serem "repatriados" pelo intermédio do governo brasileiro com base na comprovação da cidadania brasileira. Fontes orais e também escritas, expedidas ou recebidas pela Missão Militar Brasileira e pelo Office of Military Government for Germany U.S, responsável pela administração de parte da Alemanha ocupada, nos permitem apreender o fenômeno da manipulação identitária entre um grupo de pessoas desejosas de retornar ao Brasil e que tinha dupla cidadania, a brasileira e a alemã, logo após a guerra. A manipulação identitária foi operada pelo realce do nascimento no Brasil, o que fundamentaria, pelo direito brasileiro, pautado no jus solis, a cidadania brasileira e, com isso, o direito à repatriação naquele contexto. A noção de

11 A caracterização Neger (negro), em língua alemã, difundida com o colonialismo e pelas teorias raciais, é considerada politicamente incorreta na atualidade por expressar conotação discriminatória. Mas ela subsiste na linguagem coloquial e em diversos círculos de extremismo de direita. A conotação dessa palavra guarda distinções em relação à palavra negro utilizada no Brasil.

12 O antropólogo Roberto DaMatta (1984) define o "jeitinho" como a forma utilizada pelo brasileiro para burlar normas e leis, através da utilização do sistema de relações pessoais. Seria o "resultado de um sistema social dividido e até mesmo equilibrado entre duas unidades sociais básicas: o indivíduo (o sujeito das leis universais que modernizam a sociedade) e a pessoa (o sujeito das relações sociais, que conduz ao pólo tradicional do sistema)"; entre os dois, estaria o "jeitinho", um modo de enfrentar essas contradições e paradoxos de modo tipicamente brasileiro (DaMatta, 1984, p. 95-97). 
realce, operada pelas teorias da etnicidade, permite desconstruir a ideia de identidade enquanto essência e perceber como os indivíduos podem assumir uma ou outra das identidades que lhe são disponíveis de acordo com as situações nas quais eles se localizam e as pessoas com quem interagem (Poutignat; Streiff-Fenart, 1998, p. 166).

Através da entrevista de Ruth, se apreende que o realce de sua cidadania brasileira ao soldado norte-americano significou a expressão de um posicionamento identitário interessado e, também, uma maneira de fazer coisas com palavras. $\mathrm{O}$ fato de sua autoidentificação enquanto brasileira naquele momento ter ocorrido apenas por razões práticas e interessadas fica claro noutra parte da entrevista, quando ela se refere ao Holocausto e se autoidentifica como alemã: “Aí nós, alemães, só temos é que nos envergonhar...” Tratamos, portanto, de posições de identidade influenciadas pelas situações vividas no passado e no presente, incluindo aí as próprias situações da entrevista.

$\mathrm{O}$ trecho citado anteriormente nos lembra do caráter dialógico das fontes orais. A entrevistada interagiu de maneira direta com a entrevistadora, construindo um relato em que o dizível e o indizível estão ligados à relação estabelecida durante a conversa. Segundo Certeau (2005, p. 40), o ato de falar (enunciação) "estabelece um contrato com o outro (o interlocutor), numa rede de lugares e relações”. Sendo assim, levar em conta as circunstâncias enunciativas da entrevista é fundamental ao se refletir sobre a fala, isso porque há uma relação complexa entre circunstância da entrevista, enunciação e língua(gem). Vejamos. No caso aqui analisado, a entrevistada usou uma expressão em português por ter percebido a curiosidade despertada pela estória e também por ter reconhecido a entrevistadora como uma brasileira, a qual, por mais que fale a língua alemã e conheça muitos códigos culturais associados a esse idioma, tem o português como língua mais fluente. A alternância para a língua portuguesa nesse momento de ápice da narração, portanto, pode estar relacionada às diferentes histórias de convivência com a língua alemã entre entrevistadora e entrevistada e com a própria diferença de geração entre ambas. Descendentes de alemães da idade da entrevistadora, 50 anos mais nova que a entrevistada, em contextos urbanos no sul do Brasil, em geral não falam mais a língua alemã.

Ao iniciarmos o trabalho de produção de histórias de vida com pessoas que se deslocaram entre Brasil e Alemanha na primeira metade do século XX, pudemos observar a dificuldade de algumas pessoas de idade mais avançada de se expressar em português, por terem vivido num ambiente sociocultural 
em que traços da cultura e da língua alemãs são ainda relativamente mantidos. Nesses casos, o uso da língua alemã nas entrevistas poderia facilitar a rememoração de fatos e processos. Isso também poderia facilitar a menção a determinados fatos ou temas, alguns deles traumáticos, como é o caso da guerra e da ocupação da Alemanha, ou desconfortáveis, como o nazismo. Com isso não queremos dizer que estas entrevistas sejam mais "verdadeiras" e "completas" que as feitas noutra língua. ${ }^{13}$

O psicólogo social Harald Welzer (2002), ao discutir descobertas das neurociências e da psicologia cognitiva, aponta que o processo de rememoração é facilitado quando ele ocorre em circunstâncias sociais semelhantes àquelas do fato vivido. Isso faz com que, por exemplo, em encontros de camaradas que lutaram juntos na guerra ou de pessoas que viveram numa mesma localidade durante aquele período haja maior abundância de recordações da guerra do que em entrevistas de história de vida feitas no interior de um projeto de pesquisa (Welzer, 2002, p. 37-38). Mesmo levando isso em conta, entendemos que numa situação de entrevista, o emprego da mesma língua usada durante os acontecimentos ocorridos no passado e dos quais se trata na conversa pode facilitar a rememoração.

A psicóloga social Ecléa Bosi, mesmo que não se refira especificamente à língua ou a idioma, mas à linguagem, a qual abrange diversas formas de expressão, conecta memória à linguagem. Ao se dedicar à reflexão sobre lembranças de velhos, a autora lembra que a memória não é pura, mas mediada pela linguagem: "O instrumento decisivamente socializador da memória é a linguagem.” (Bosi, 1994, p. 56).

O compartilhamento de elementos socioculturais e linguísticos entre entrevistador e entrevistado, ou pelo menos a imaginação de que o entrevistador seja integrante da mesma "comunidade de fala", pode influir no conteúdo, forma, fluxo e profundidade de uma entrevista. ${ }^{14}$ Em que pesem inúmeras diferenças existentes entre os falantes de alemão no Brasil, tanto no

13 Sobre memórias de guerra e do nazismo em duas gerações de uma mesma família de descendentes de alemães no Brasil, ver Frotscher (2011).

14 Peter Burke (1995, p. 18) emprega a ideia de "comunidade de fala" tanto para descrever traços comuns do falar quanto para fazer referência à identificação individual ou de um grupo com formas de falar específicas. Adverte que, com isso, não pressupõe a ausência de conflitos, linguísticos ou de outro tipo, ou a sobreposição entre uma comunidade definida em termos linguísticos e as comunidades sociais ou religiosas a serem encontradas na mesma região. 
passado como na atualidade, notamos que, em diversos casos, o uso da língua alemã facilitou a realização das entrevistas.

A possibilidade de usar a língua alemã permitiu também a alguns entrevistados o emprego de expressões contemporâneas aos fatos vividos na Alemanha, sem a necessidade de tradução e maiores explicações à interlocutora. O problema maior reside, entretanto, na publicação desses relatos orais numa língua que não é a utilizada nas entrevistas, pois é necessário traduzir e informar ao leitor os sentidos expressos na outra língua. Esse cuidado deve ser maior ainda quando se discute a relação entre linguagem, identidade e diferença, já que, como aponta Tomaz Tadeu da Silva (2005, p.78), identidade e diferença não podem ser compreendidas "fora dos sistemas de significação nos quais adquirem sentido”.

Isso fica claro através de um trecho de entrevista realizada com um alemão, o qual chamaremos de Ernst Eders, que chegou com sua família em Joinville, estado de Santa Catarina, aos dois anos de idade na década de 1920. Em 1939, influenciado pelas impressóes positivas de um colega que havia recém-visitado a Alemanha, Ernst retornou sozinho para aquele país para servir ao exército. Uma lei de 1935 havia reinstituído a obrigatoriedade do serviço militar na Alemanha, inclusive também aos chamados Auslandsdeutsche (cidadãos alemães no exterior). ${ }^{15}$ Como outros jovens, Ernst prestou primeiramente serviços ao Reichsarbeitsdienst, como preparação para o serviço militar, e quando começou a guerra serviu ao exército até ser capturado como prisioneiro de guerra pelos ingleses no front ocidental. ${ }^{16}$

Durante a entrevista, ele descreve, às vezes com humor irônico, sua longa trajetória de vida. Relata a infância e adolescência no espaço rural de uma colônia de imigrantes em Joinville, as primeiras impressões na Alemanha, as vivências em diversos fronts na Europa, sua vida como prisioneiro de guerra na Inglaterra, o casamento e a emigração para o Canadá com a esposa inglesa e seus dois filhos, após a guerra, e seu retorno, sozinho e na condição de divorciado, a Joinville após a aposentadoria.

15 “Wehrpflicht für Auslandsdeutsche, Gesetz von 1935”. Pasta R 57 NEU - 653. Arquivo Nacional, Berlim.

16 A partir de junho de 1935, todo jovem alemão deveria prestar serviços, durante seis meses, para o Reichsarbeitsdienst, como preparação para o serviço militar. Esta era uma organização do aparato nacionalsocialista que tomava parte do programa econômico e do sistema de educação nacional-socialista e que teve papel importante para a preparação da guerra. Sobre isso ver verbete "RAD, Reichsarbeitsdienst" em Kammer e Bartsch (1992, p. 158-159). 
Segundo ele, em 1939 embarcou em Florianópolis, juntamente com outros 17 jovens, todos também de Santa Catarina, rumo à Alemanha. Ao contar sobre os pais e o irmão, que depois dele, mas ainda antes da guerra, também retornaram à Alemanha, reproduz expressão utilizada naquela época por muitos que estavam retornando:

Wir hatten so nen Witz: "Wir wollen heim ins Reich, uns reicht's" [lachen beide]. Das war ja hier damals vor dem Krieg, die Deutschen hatten ja eigentlich auch ein ziemlich grosses Maul. Und dass das den Brasilianern nicht gefallen hat, das kann man verstehen. (Ernst Eders, entrevista em $03 / 10 / 2009) \cdot{ }^{17}$

A frase "Nós queremos retornar à pátria, estamos fartos!" constitui um jogo de palavras que inclui a expressão Heim ins Reich (retorno à pátria), um slogan utilizado pelo regime nacional-socialista e instrumentalizado como propaganda política. Ele já fora utilizado, por exemplo, no contexto do plebiscito que havia decidido pela reincorporação do Sarre ao Reich, em janeiro de 1935. Portanto, a tradução da expressão Heim ins Reich simplesmente enquanto um "retorno à pátria" não seria capaz de expressar os sentidos político-ideológicos ali contidos. ${ }^{18}$ Ela não se referia simplesmente a um "retorno à pátria", pois não se tratava de qualquer pátria e nem de qualquer retorno.

$\mathrm{Na}$ historiografia alemã a expressão Heim ins Reich se refere à incorporação de determinados territórios sob o governo nacional-socialista e ao deslocamento coordenado de grupos de descendentes de alemães que viviam fora das fronteiras políticas alemãs para dentro delas durante e/ou em razão do regime nacional-socialista. Por isso, o termo aparece em títulos de obras sobre o Anschluss (anexação) da Áustria e a incorporação dos sudetos ao Reich alemão, ambos em 1938, a evacuação de alemães da Espanha durante a guerra civil naquele país, ao deslocamento de populações "alemãs" que mora-

17 “Nós tínhamos assim uma piada: 'Nós queremos retornar à pátria, estamos fartos!' [risos]. Isso era ainda antes da guerra aqui e os alemães tinham também uma boca bastante grande. Isso não agradava aos brasileiros, isso a gente pode entender."

18 O filólogo Victor Klemperer (2009), logo após a guerra, em 1947, publicou uma refinada análise da manipulação da linguagem durante o Terceiro Reich. Sobre a Lingua Tertii Imperii (LTI). 
vam no Leste Europeu para dentro das fronteiras políticas do Estado alemão, sob coordenação do governo nazista. ${ }^{19}$

Em diversas cartas escritas por retornados oriundos do Brasil, a remigração para a Alemanha também é caracterizada como um movimento Heim ins Reich, mesmo que o retorno a partir do Brasil não fizesse parte da política oficial alemã. Também a frase expressa pelos colegas do entrevistado, por ocasião do embarque rumo à Alemanha, revela a apropriação daquele lema nacional-socialista.

Além de utilizar o lema Heim ins Reich, a frase "wir wollen heim ins Reich, uns reicht's!” (Nós queremos retornar à pátria, estamos fartos!) faz um trocadilho com palavras de grafia aproximada, o substantivo Reich (império alemão) e o verbo conjugado reicht (basta), para expressar tanto a firme vontade de voltar à pátria (Heim provém de Heimat = pátria), como o descontentamento em relação ao Brasil. Ela é, assim, a materialização linguística dos pull e push factors (fatores de atração e de repulsão) daquela migração e de seus sentidos político-ideológicos.

Tanto Ernst como Ruth, nascidos no início dos anos 1920, concederam entrevista em língua alemã. A maioria das entrevistas - um total de 21 - foi feita nesta língua. Dois entrevistados, ambos oriundos de contextos urbanos, onde o contato com alemães e descendentes era pequeno, fizeram questão de conceder entrevista em português.

A seguir, nos deteremos com mais detalhes na entrevista com um deles, doravante chamado pelo pseudônimo de Paulo Binsle, um professor universitário aposentado que nasceu e mora, desde a "repatriação", na cidade de São Paulo. Ele ainda era uma criança quando foi "repatriado" junto com os pais ao Brasil, enquanto os dois entrevistados mencionados anteriormente vivenciaram a guerra sem a companhia dos pais e já enquanto adultos.

O contato com Paulo não foi feito através do sistema "bola de neve", através do qual conhecemos a maioria dos entrevistados, os quais iam indicando outros, em geral moradores de áreas com presença de descendentes de alemães no sul do Brasil, como foi o caso de Ruth e Ernst. Localizamos Paulo após acesso às listas dos "repatriados" pela Missão Militar Brasileira,

19 É o caso de livro sobre a anexação da Áustria (Zentner, 1988), de livro sobre a incorporação dos sudetos (Gebel, 1999), de obra sobre os alemães evacuados da Espanha em razão da guerra civil espanhola (Norden, 1998) e da tese de Markus Leniger (2006) sobre a política de deslocamento de populações de origem alemã sob o governo nacional-socialista, cujo livro tem outro título. 
encaminhadas ao Ministério das Relações Exteriores do Brasil. Esse procedimento se mostrou muito apropriado, pois permitiu contatar pessoas fora daqueles círculos e, assim, perceber trajetórias de outros imigrantes e, principalmente, outras experiências de reinserção após a "repatriação".

Nascido no Brasil, Paulo foi levado aos dois anos de idade pelos pais à Alemanha pouco antes do irromper da II Guerra Mundial, assim como Ernst e Ruth. Paulo foi "repatriado" com os pais em 1947 e retornou para São Paulo. Diferentemente de outros "repatriados" que voltaram para contextos teuto-brasileiros, Paulo encontrou um ambiente sociocultural e linguístico no qual tinha poucas chances de falar alemão. Isso incidiu não apenas nas suas vivências e na construção de narrativa sobre o passado, como também na própria escolha da principal língua empregada na entrevista, como veremos.

Após ser oferecida a opção de conceder a entrevista em alemão, Paulo titubeou constrangido em alemão, e logo em seguida passou a relatar sua história de vida em português: "Vou tentar o alemão. Ich weiss nicht ob es gehen wird [risos], aber... Bom, [vou] começar pelos meus pais" (Paulo Binsle, entrevista em 31/05/2010). A frase em alemão, traduzida, "Eu não sei se vai funcionar [risos], mas...", longe de significar dificuldade em falar em alemão, revela certo desconforto em falar nessa língua com a entrevistadora. Os motivos e os significados da sua escolha aparecem ao longo da análise da entrevista, como veremos mais adiante.

Paulo é filho único de um imigrante alemão natural da Suábia e de uma imigrante húngara de origem alemã, cuja família há gerações havia se instalado no antigo Império Austro-Húngaro, na atual Romênia. Assim, ela mantinha fortes traços culturais alemães, inclusive a língua. Ambos se conheceram no Brasil e se casaram na década de 1920. Com eles Paulo falava sempre em alemão, até o fim de suas vidas: "Minha mãe era húngara, mas falava alemão fluentemente, por causa do Império Austro-Húngaro. Ela não... entende? Não se falava... Eu não conseguia falar português com meus pais.”

Falar alemão significava, para ele, falar com os familiares. Exceções eram os contatos acadêmicos esporádicos com professores alemães que vinham trabalhar na universidade. Assim ele comenta sobre esses contatos: "Agora, pra mim, foi uma experiência muito interessante voltar a falar alemão com alguém que não seja da minha família. Porque aqui eu não tenho nenhuma oportunidade de falar alemão com ninguém."

Sociolinguistas, etnolinguistas e analistas de discurso interessados em estudar as razões das escolhas de língua feitas por pessoas com o "mesmo" 
bilinguismo têm apontado fatores como origem linguística dos interlocutores, competência dos mesmos, repertório, tema do enunciado, influência do ambiente, presença de um terceiro, entre outros (Serrani-Infante, 1998, p. 243). No caso de Paulo, podemos vislumbrar, além dos dois primeiros fatores mencionados e a influência do ambiente no momento da entrevista, outros que o podem ter levado a falar predominantemente em português. Um deles tem a ver com o seu passado de inserção numa localidade com pouca presença de alemães, como ele esclareceu.

Além disso, assim como lhe parecia artificial falar em português com os pais, lhe pareceu estranho a possibilidade de conceder entrevista em alemão a uma historiadora nascida no Brasil, reconhecida por ele como alguém que compartilhava códigos da academia brasileira, como ele sugere, ao comentar aspectos da política universitária: “[...] a senhora deve saber como é." Talvez uma das razões também seja a familiaridade que estabeleceu com determinada forma de falar alemão.

Apesar disso, ao longo da entrevista, ele utiliza diversos termos em alemão para se referir a coisas, fatos, ações, frases de terceiros e até mesmo para caracterizar a sua personalidade. Sobretudo a mudança de língua ao falar de si nos interessa aqui, pois permite refletir sobre a complexa relação entre língua, memória e identidade.

Ao explicar a estreita ligação com seus pais, sobretudo com a mãe, da qual cuidou até o falecimento em idade avançada, Paulo relata:

Passamos a guerra juntos. E eu vi o que eles fizeram por mim e ficou uma ligação muito forte. E outra coisa: eu nunca achei que eu ia me casar com uma moça de outra cultura, [que] pudesse compreender o nosso esquema de vida, entende? Então eu sempre pensei comigo, eu não posso precipitar uma situação na qual eu não tivesse saída ou que ficasse entre minha nova família e os meus pais, entende? Então isso já era uma coisa que eu pensava quando eu tinha 16, 17 anos. E como nós nos, o meu pai era muito recluso, ele não fazia parte de clubes, nunca foi ao cinema no Brasil, ele era muito ligado nas coisas que ele fazia, natureza, a escultura, o próprio trabalho dele, e ele... Eu não tive a oportunidade de conhecer, digamos, como provavelmente é muito comum no Rio Grande do Sul, no Sul, os alemães vão nos clubes e conhecem filhos de alemães. Às vezes dá certo casar fora, mas às vezes não. E eu achei que a minha estratégia era melhor, e como eu sou um tipo bastante, como se diz, Eigenbrötler, como se diz, 
bastante autossuficiente, então eu consegui tomar essa decisão e até hoje eu vivo muito feliz, eu não tenho problema nenhum. Me ocupo com muitas coisas, tenho trabalho, tenho amigos, tenho amigas, eu acho que nem me daria bem, convivendo com alguém. É uma questão de modo de ser. Porque desde, eu acho, desde criança, como havia muitos bombardeios na Alemanha e muitos deslocamentos, eu não me acostumei a ter turma em volta de mim, entende? (Paulo Binsle, entrevista em 31/05/2010).

Ao caracterizar sua personalidade, Paulo realiza um switch linguístico, pois assim ele consegue expressar numa única palavra - Eigenbrötler - o que em português precisaria explicar numa ou mais frases. Eigenbrötler, segundo o dicionário Duden, significa "pessoa que se isola, que resolve seus assuntos sozinha e ao seu modo, e que, por conta deste comportamento, parece estranha aos outros"; originalmente a palavra significava, em linguagem coloquial do sudoeste da Alemanha, "jovem solteiro que fazia o seu próprio pão".

O trecho acima nos permite apreender a construção de identidade na língua e através dela. Segundo o linguista Kanavillil Rajagopalan (1998), assim como as identidades individuais não são puras, íntegras e totalizadas, as línguas individuais também não devem ser tomadas como conjuntos plenamente integrados e autossuficientes. Ao problematizar a noção de "língua" e "identidade", observa o autor: "a identidade de um indivíduo se constrói na língua e através dela. Isso significa que o indivíduo não tem identidade fixa anterior e fora da língua." (Rajagopalan, 1998, p. 41).

No caso de Paulo, a autoidentificação Eigenbrötler, é utilizada para identificar um determinado "modo de ser" e também para justificar o seu estado civil. Questões de gênero e também étnicas encontram-se entrelaçadas nessa autoidentificação. Isso porque a autoidentificação expressa em alemão é citada logo após ele, no processo dialógico estabelecido com a interlocutora, ter comparado a suposta vida social dos alemães no sul do Brasil com a da sua família em São Paulo. O sul do país, utilizado como contraponto e, para tanto, tomado como unidade homogênea, é representado como região onde o contato com alemães seria maior e, portanto, propícia a um casamento com alguém do grupo.

A referência a isolamento e a um sentimento de autossuficiência, que ele associa à palavra Eigenbrötler, está presente em outros trechos da entrevista,

20 Verbete "Eigenbrötler" (http://www.duden.de/rechtschreibung/Eigenbroetler). Tradução livre. 
quando outros fatos do passado são utilizados para justificar ou pelo menos reforçar a existência de uma personalidade diferente, um peculiar "modo de ser", como ele ressalta.

No final da entrevista, a reconstrução de uma "cena" da infância ilustra a ideia de Eigenbrötler expressa anteriormente. Trata-se curiosamente de um episódio envolvendo pão (Brot), relatado também através da utilização de algumas palavras e frases em alemão:

Eu lembro muito bem de uma cena que marcou a minha maneira de ser. Nós estávamos em quatro, cinco, e havia um Bauer, um Bauer, er hatte einen Bauernhof [agricultor, ele tinha uma propriedade rural], ele tava lá trabalhando na horta dele e nós estávamos olhando. E ele disse assim: "Wer da bleibe will, muss schaffe. Und wenn er schafft, kriegt er Gsälzbrot." [quem quiser ficar aí tem que trabalhar. E quem trabalhar ganha um Gsälzbrot]. Gsälzbrot é um pão com geleia. Olha, isso era pra uma criança esfomeada, era uma coisa impensável. Todo mundo, menos eu, foi correndo pegar uma enxada e fazer alguma coisa. Eu voltei pra casa e a minha mãe me contou, eu pedi pra minha mãe que me desse um Schmalzbrot [pão com banha], ela pegou um pão, pegou um pouquinho, só pra encher os buraquinhos e me deu. E ela me disse que eu comi aquilo com o maior gosto do mundo. Entende? Veja, esse é, foi um bom indício do meu modo de ser. Eu não sou comprável, entende? Eu não sou comprável. Eu posso até pegar a enxada se me falarem direito e me tratar bem, com respeito, eu sou até capaz de fazer, por nada, mas se começar a me tratar como um escravo, eu já pulo fora, já desde criança. (Paulo Binsle, entrevista em 31/05/2010).

Aqui podemos encontrar conexões entre o uso da metáfora Eigenbrötler e as condições materiais vividas no passado, numa época de muita fome. Curioso notar que a única palavra em alemão traduzida durante a conversa à entrevistadora é Gsälzbrot, um regionalismo do sudoeste da Alemanha, onde se fala o dialeto $S$ chwäbisch. As duas frases em alemão, a que esclarece o fato do senhor ser o dono de uma propriedade rural e a que reproduz a sua fala esta em dialeto -, não são traduzidas, pois talvez o entrevistado presumisse que elas seriam entendidas pela interlocutora. Além delas, também a palavra $S c h m a l z b r o t$ não é traduzida. Fatias de $S$ chmalzbrot (pão com banha) faziam parte também do cardápio cotidiano em muitas áreas de imigração alemã 
no Brasil, sendo a expressão ainda hoje conhecida por muitos descendentes falantes do alemão no país.

Paulo também usa palavra em alemão para reproduzir como os colegas da localidade onde vivia na Alemanha o representavam. Conhecendo sua origem brasileira, eles o chamavam pejorativamente de Urwaldsimpel, a qual poderia ser traduzida como pessoa simples e limitada oriunda da floresta virgem:

O meu pai era tratado como alemão, porque ele era alemão de uma família, vamos dizer, Bürger, Bürgerfamilie [burguês, família burguesa], lá da região. Agora a minha mãe, interessante, ela tinha muitas amigas alemãs porque ela era uma pessoa muito inteligente e muito interessante. Ela falava alemão com sotaque húngaro, tinha uma famosa atriz alemã que era húngara lá, da época, e minha mãe falava alemão exatamente como essa atriz falava, entende, então ficava tudo bem. Achavam até chique, sabe, esse tipo de coisa. Eu não me lembro mais o nome da atriz, mas era uma conhecida atriz alemã que falava aquele alemão meio arredondado dos húngaros, né, entende? Agora eu, na Alemanha, eles me chamavam de Urwaldsimpel $[$ Urwald $=$ floresta virgem; Simpel $=$ pessoa simples e limitada $]$. Eu era Urwaldsimpel, era uma gíria lá... (Paulo Binsle, entrevista em 31/05/2010).

Apenas o pai, natural da localidade, seria considerado alemão e respeitado por ser oriundo de família burguesa. Esse pertencimento social é expresso em língua alemã (Bürgerfamilie), por conta de todo um conjunto de imagens e valores que, no contexto alemão, se associava e ainda se associa aos integrantes daquela classe social. A mãe, muito embora fosse vista como diferente do grupo estabelecido, segundo ele, seria aceita devido à sua educação e origem social - era filha de funcionário público no Império Austro-Húngaro - e ao seu sotaque, admirado pelos alemães por conta da semelhança com o sotaque da famosa atriz.

Com a expressão "Agora eu”, para iniciar nova frase, Paulo quebra o sentido positivo do que foi dito anteriormente e marca uma ruptura na narrativa no intuito de explicar como ele, diferentemente do pai e até da mãe, teria sido tratado de forma pejorativa. A identificação Urwaldsimpel estava imbuída de antigas representações sociais do Brasil veiculadas na Europa e que associavam o país a imagens da natureza selvagem. ${ }^{21}$

21 Verbete "Simpel” (http://www.duden.de/rechtschreibung/Simpel). Tradução livre. 
As autoidentificações construídas por Paulo e a menção às identificações de outrem sobre ele, presentes em sua narrativa autobiográfica, envolvem questões do passado e também necessidades do presente. A história de vida construída por ele é perpassada por uma insistente acentuação do seu "modo de ser".

Assim como outras histórias de vida contadas, a sua é produzida através de um complexo processo construído no presente em que não se pode separar passado, memória e narrativa. Passado e presente estão entrelaçados na composição de sua autoidentificação, processada por meio do contraste com outras pessoas com as quais conviveu e por meio das relações estabelecidas na entrevista.

É notório como sua fala sobre o passado vivido e sentido é articulada no sentido de explicar os traços de sua personalidade. Segundo sua narrativa, ela teria sido conformada por situações vividas durante a infância, as quais envolveram medo, fome, carência material e isolamento social. Em relação ao vivido na Alemanha, ele acentua o seguinte: "Agora, eu digo pra senhora, eu tenho muitas lembranças da Alemanha e ela é muito parte do meu modo de ser, entende?" A guerra e o cotidiano nos campos de refugiados o teriam unido de maneira muito intensa aos pais eà Alemanha:

Eles [os pais] se davam muito bem e eu me dava muito bem com eles. Tanto é que eu permaneci solteiro por uma série de razões. Eu ainda hoje tenho amigos alemães, que têm a nacionalidade alemã, eu tirei [obtive a cidadania alemã]. Eu me sinto muito ligado à Alemanha, porque foi uma experiência muito importante na minha vida, dos 2 aos 12 anos, fiz a escola primária lá, sofri os bombardeios. Sofremos todas as agruras da guerra, vivi em campo de refugiado em tudo quanto é lugar da Alemanha, até que pudéssemos voltar. (Paulo Binsle, entrevista em 31/05/2010).

Notável ter exatamente ele, morador de uma metrópole e que concedeu a entrevista em português, acentuado tanto seus laços afetivos com a Alemanha. Com dificuldade de expressar sentimentos em palavras, tanto em português como em alemão, ele convida a entrevistadora a ver fotos da família: "Talvez eu possa mostrar algumas fotos que talvez ilustrem melhor isso, esse sentimento." Ele tenta recorrer a outra linguagem, a visual, para potencializar aquilo que ele procura, com dificuldade, expressar em palavras. Esse gesto revela o quanto se sente limitado para expressar seus sentimentos via 
linguagem oral, mesmo podendo usar duas línguas naquela situação de entrevista. Por isso, procura “compartilhá-los" através do estímulo de fotografias. ${ }^{22}$

As dificuldades de expressar os sentimentos através desta ou daquela língua pulverizam o entendimento, muitas vezes presente, de que é possível apreender a realidade vivida no passado via linguagem, pois ela não é um reflexo daquela. As próprias mudanças de língua durante as entrevistas realizadas demonstram as dificuldades desses migrantes de expressar vivências, sentimentos, circunstâncias pelas quais passaram.

Voltando à entrevista, os vínculos que expressa ter com a Alemanha em razão de seu passado familiar não são os únicos ao falar de si. Assim ele se refere a conversas com colegas alemães, quando notam que ele não é um conterrâneo: "Aí eles me perguntam se eu não sou suíço. Falo, 'não, eu não sou suíço, primeiro eu sou brasileiro, mas...' Daí eu conto um pouco da minha história, da Alemanha...” As reticências expressam sua trajetória transnacional e uma identidade híbrida, construída a partir das vivências no Brasil e na Alemanha.

O raciocínio matemático, exercido ao longo de sua profissão, está presente em sua narrativa autobiográfica. Segundo ele, ter permanecido solteiro teria sido decorrência da construção de uma subjetividade moldada por diversas experiências de vida, mas também de uma "decisão" longamente refletida e calculada. Essa decisão, acentuada algumas vezes durante a entrevista, teria ocorrido com o objetivo de preservar o pequeno núcleo familiar, ele e seus pais. A construção de seu "modo de ser" teria sido consequência lógica de diversos acontecimentos do passado. É o que fica perceptível num dos momentos da entrevista: "Eu falei isso pra reforçar aquilo que eu falei da minha personalidade." A entrevista, de forte teor autobiográfico, tornou-se um espaço de explicação de si e, ao mesmo tempo, de construção de um perfil de si para a interlocutora.

Paulo cita outra situação de isolamento vivida na infância, quando se refere ao cotidiano dos campos de refugiados na Alemanha após a guerra e aos primeiros momentos após a "repatriação" no Brasil:

Era uma promiscuidade imensa. Não era uma boa experiência pra uma criança, mas enfim... Muita miséria humana, muita coisa feia. Enfim, com

22 Ao final da gravação, o entrevistado mostrou e comentou, com muito interesse, diversas fotografias, assim como documentos da família. 
tudo isso, como eu disse, eu fui ficando solitário, quer dizer, não tive essa educação de ter a minha turminha de... que crescia comigo. E aqui no Brasil, no começo, eu senti muito a diferença de atitude dos brasileiros, das crianças, dos colegas brasileiros, em relação ao que eu era. Como digo, aqui no Brasil é, o pessoal era bastante malicioso, dizia uma coisa, fazia outra, debochavam, gozavam. Por exemplo, pra dar um exemplo que me marcou muitíssimo. Minha mãe tinha tricotado um pulôver pra mim, que eu adorava. E esse pulôver era, tinha Hirsch, Hirsche [veado, veados], aqui [no peito], tricotado. Sabe, eu era alvo de tanta chacota, de tanta gozação, que tiraram o pulôver de mim e eu não entendia porque tiraram o pulôver de mim, entende? Esse tipo de malícia. Eu andava de calça curta, por muito tempo. Era outra vez motivo de chacota. Tinha aquelas calças de couro da Bavária...

[Entrevistadora:] Sim, Lederhose.

É, Lederhose. Talvez no Sul pudesse, aqui foi impossível. Então, tudo isso são pequenos choques que de alguma maneira... Como eu tenho uma natureza muito dura, não sou muito facilmente impressionável e nem adaptável. Ninguém me muda com muita facilidade quando eu tô convencido que eu estou certo. E isso desde criança. E eu tava convencido que eu é que estava certo. E eu não entrei em turma nenhuma e me sentia muito bem assim. Eu lia muito quando era menino. Comecei a estudar matemática avançada por conta própria e esse tipo de... não saía muito. (Paulo Binsle, entrevista em 31/05/2010).

A associação maliciosa entre veado e homossexualidade, fortemente presente no contexto cultural brasileiro, não é compreendida num contexto cultural alemão. ${ }^{23} \mathrm{Ou}$ seja, enquanto a imagem do veado acionava simbologias preconceituosas nas crianças brasileiras, para Paulo, ela remetia a outras ideias. Aquela associação não lhe era conhecida naquela época. Pessoalmente o pulôver lhe era muito importante, pois havia sido tricotado pela mãe numa época de muita carência material. Por isso, não conseguia entender por que uma peça de roupa pudesse se tornar alvo de deboche e violência.

23 A associação pejorativa entre o veado e a homossexualidade no Brasil também está presente no universo do futebol. Jogadores e torcedores do São Paulo Futebol Clube são alvo de deboche até hoje pelos torcedores de times adversários, os quais os chamam de bambis (uma referência ao veado personagem-título do conhecido filme de Walt Disney, lançado no Brasil em 1942). 
Com base nas considerações de Lewis A. Coser, autor do prefácio de tradução para a língua inglesa dos estudos de Maurice Halbwachs sobre memória coletiva, o historiador Alexander Freund (2009, p. 1-2) aponta para a falta de estudos sobre o alheamento vivido por muitos migrantes por não compartilharem de lembranças em comum com as pessoas do novo meio: "Quando as pessoas migram, elas não só perdem a sua ligação com a memória coletiva de sua terra natal, mas ao mesmo tempo elas entram num ambiente cuja memória coletiva lhes é alheia." Segundo o autor, esse fenômeno de duplo alheamento e falta de orientação é descrito por muitos migrantes através de uma imagem que mostra o quanto se sentem perdidos entre dois mundos ou até mesmo dilacerados (Freund, 2009, p. 2).

No episódio narrado por Paulo, tanto o casaco com Hirsche quanto as "calças curtas de couro" funcionam como símbolos da exclusão sociocultural vivida por ele após o retorno. A menção ao tradicional traje típico alemão lhe serve para reforçar o argumento de que as diferenças socioculturais eram muito grandes, resultando daí, segundo ele, "pequenos choques". A intervenção da entrevistadora com o objetivo de confirmar o que ele se referia, através da menção à palavra Lederhose, o faz diferenciar o cotidiano de São Paulo com o de localidades com forte presença de descendentes de alemães no sul do país, onde a Lederhose era pelo menos conhecida. O sobrenome e a origem da entrevistadora, oriunda de Blumenau, uma cidade fundada por imigrantes alemães e hoje divulgada pela indústria do turismo como uma espécie de "Alemanha brasileira", eram do conhecimento do entrevistado, o que certamente interferiu no conteúdo e na forma da narrativa.

Suas experiências vividas após o retorno diferem das de outros entrevistados "repatriados" após a guerra e que se inseriram em áreas no Brasil onde havia maior familiaridade com a língua e outros traços da cultura alemã. Entretanto, estes últimos, e não somente as crianças e adolescentes, não ficaram ilesos a outros estranhamentos, devido às mudanças ocorridas entre o retorno à Alemanha e a "repatriação" após a guerra.

\section{Considerações finais}

Susan K. Burton (2006), em pesquisa baseada na metodologia do cross-cultural interviewing, através da qual entrevistou japonesas que então viviam na Inglaterra em inglês, japonês ou misturando ambas as línguas, 
pôde perceber como a escolha da língua interferiu no que foi contado a ela. A autora apreendeu como as entrevistadas, ao falar inglês e assim olhar para o mundo de uma perspectiva linguística e cultural diferente, reavaliavam sua própria identidade. Em suas considerações finais, a autora aponta que a metodologia mencionada pode ajudar os entrevistados a representar as reais contradições culturais e linguísticas das experiências migratórias de mulheres japonesas (Burton, 2006, p. 174).

Em nossa pesquisa, percebemos que não apenas a escolha da língua ou de variações linguísticas, consciente ou não, mas também a alternância delas numa situação de entrevista nos fornece elementos instigantes para discutir a complexa relação entre língua e identidade.

As condições da entrevista, as diferentes habilidades linguísticas do entrevistado e do entrevistador, experiências vividas pelo entrevistado em distintos contextos socioculturais resultaram, em nosso caso, na produção de relatos orais bilíngues em que se percebe na própria narrativa as marcas de identidades culturais e linguísticas híbridas.

Dar ao entrevistado a possibilidade de escolha da língua a ser usada ou o mero fato do entrevistado perceber no entrevistador alguém com quem possa dialogar em mais de uma língua pode resultar na constituição de relatos orais que demandam uma discussão sobre os significados desta ou daquela língua na representação do passado vivido.

Levar em conta o uso de determinadas línguas nos parece um aspecto importante a ser analisado pela historiografia dedicada às migrações sob uma perspectiva transnacional, uma vez que experiências transnacionais podem se inscrever linguisticamente na própria narrativa autobiográfica.

A história transnacional tem chamado a atenção para as interações e as transferências transnacionais de ideias, processos formadores de opinião e estilos de vida e seus efeitos em contextos locais e nacionais. ${ }^{24}$ Ao apontar os limites de uma história das migrações fixada somente nos estados nacionais, o historiador das migrações Dirk Hoerder (2008) pleiteia uma abordagem transnacional das migrações, a qual demandaria, segundo ele, uma análise transcultural.

Este artigo procurou se aproximar dessa abordagem e exercitar uma análise transcultural a partir da discussão de relatos orais produzidos na

24 Para uma introdução à história transnacional, ver Budde, Conrad e Janz (2006). 
intersecção entre diferentes línguas e culturas. Isso nos levou a discutir questões metodológicas, como o próprio processo de produção, de interpretação e de publicação desses relatos orais. Interpretá-los envolve um trabalho de tradução cultural. Traduzir as palavras e expressões ditas noutra(s) língua(s) durante a entrevista, sem considerar elementos históricos e culturais e sem analisar as possíveis razões e o significados do seu uso seria desperdiçar uma oportunidade de refletir sobre os efeitos da história das migrações na construção de identidades via língua(gem). Pois assim como a cultura, a língua também tem uma função no estabelecimento de significados, o que permite aos sujeitos posicionar sua identidade.

\section{Referências}

ALKMIM, T. M. Sociolinguística. In: MUSSALIN, F.; BENTES, A. C. Introdução à lingüistica 1.3. ed. São Paulo: Cortez, 2003. p. 21-47.

BOSI, E. Memória e sociedade: lembrança de velhos. 3. ed. São Paulo: Companhia das Letras, 1994.

BUDDE, G.; CONRAD, S.; JANZ, O. (Org.). Transnationale Geschichte: Themen, Tendenzen und Theorien. Göttingen: Vandenhoeck \& Ruprecht, 2006.

BURKE, P. A arte da conversação. Tradução: Álvaro L. Hattnher. São Paulo: Ed. Unesp, 1995.

BURTON, S. K. Issues in cross-cultural interviewing. Japanese women in England. In: PERKS, R.; THOMSON, A. The oral history reader. $2^{\text {nd }}$ ed. London: Routledge, 2006. p. 166-176.

CERTEAU, M. de. A invenção do cotidiano: artes de fazer. Tradução: Ephraim Ferreira Alves. 11. ed. Petrópolis: Vozes, 2005.

FREUND, A. Migração, memória e identidade. Narrativas de História Oral no contexto de histórias familiares e nacionais. In: ENCONTRO REGIONAL SUL DE HISTÓRIA ORAL, 5., 2009, Marechal Cândido Rondon. Anais... Marechal Cândido Rondon: Unioeste, 2009. p. 1-9.

FROTSCHER, M. Memorias de guerra y del nazismo en dos generaciones de descendientes de alemanes repatriados a Brasil. Historia, Voces y Memoria, Buenos Aires, v. 3, p. 49-78, 2011. 
GEBEL, R. „Heim ins Reich!”: Konrad Henlein und der Reichsgau Sudetenland (19381945). München: Oldenbourg, 1999.

HALL, S. Identidade cultural e diáspora. Revista do Patrimônio Histórico e Artístico Nacional, n. 24, p. 68-75, 1996.

HOERDER, D. Transnational, transregional, transcultural: Social history and labor migrants' networks in the 19th and 20th centuries. In: UNFRIED, B. et al. (Hrsg.). Transnationale Netzwerke im 20. Jahrhundert/Transnational networks in the 20th century: Historische Erkundungen zu Ideen und Praktiken, Individuen und Organisationen/Ideas and practices, individuals and organizations. Linz: AVA-Akademische Verlagsanstalt, 2008. p. 81-98.

KAMMER, H.; BARTSCH, E. Nationalsozialismus: Begriffe aus der Zeit der Gewaltherrschaft 1933-1945. Reinbek bei Hamburg: Rohwohlt, 1992.

KLEMPERER, V. LTI: a linguagem do Terceiro Reich. Tradução de Miriam Bettina Paulina Oelsner. Rio de Janeiro: Contraponto, 2009.

LENIGER, M. Nationalsozialistische „Volkstumsarbeit” und Umsiedlungspolitik 1933-1945: von der Minderheitenbetreuung zur Siedlerauslese. Berlin: Frank \& Timme, 2006.

PORTELLI, A. A filosofia e os fatos. Narração, interpretação e significado nas memórias e nas fontes orais. Tempo, Rio de Janeiro, v. 1, n. 2, p. 59-72, 1996.

DAMATTA, R. O que faz o brasil, Brasil? Rio de Janeiro: Rocco, 1984.

NORDEN, J. van. "Heim ins neue Deutschland Adolf Hitlers”: die Evakuierung der Spaniendeutschen während des Spanischen Bürgerkrieges. Saarbrücken: Verlag für Entwicklungspolitik Saarbrücken, 1998.

POUTIGNAT, P.; STREIFF-FENART, J. Teorias da etnicidade: seguido de grupos étnicos e suas fronteiras de Fredrik Barth. Tradução de Elcio Fernandes. São Paulo: Fundação Editora da Unesp, 1998.

RAJAGOPALAN, K. O conceito de identidade em lingüística: é chegada a hora para uma reconsideração radical? In: SIGNORINI, I. (Org.). Lingua(gem) e identidade: elementos para uma discussão no campo aplicado. Campinas: Mercado de Letras; São Paulo: Fapesp, 1998. p. 21-45.

SERRANI-INFANTE, S. Identidade e segundas línguas: as identificações no discurso. In: SIGNORINI, I. (Org.) Lingua(gem) e identidade: elementos para uma discussão no campo aplicado. Campinas: Mercado de Letras; São Paulo: Fapesp, 1998. p. 231-264. 
SILVA, T. T. da. A produção social da identidade e da diferença. In: SILVA, T. T. da (Org.).; HALL, S.; WOODWARD, K. Identidade e diferença: a perspectiva dos estudos culturais. Tradução Tomaz Tadeu da Silva. 4. ed. Petrópolis: Vozes, 2005. p. 73-102.

TAVARES, A. de L. Quatro anos na Alemanha ocupada. Rio de Janeiro: Biblioteca do Exército, 1951.

TAVARES, A. de L. Die brasilianische Militärmission in Berlin (1946-1949)/A Missão Militar Brasileira em Berlim (1946-1949). Deutschbrasilianische Hefte/Cadernos GermanoBrasileiros, Bonn, n. 5, p. 296-307, 1990.

WELZER, H. Das kommunikative Gedächtnis: eine Theorie der Erinnerung. 2. ed. München: Verlag C. H. Beck, 2002.

ZENTNER, C. Heim ins Reich: der Anschluss Österreichs 1938. München: SüdwestVerlag, 1988.

Resumo: $\mathrm{O}$ artigo discute os significados do uso de determinada(s) língua(s) e de mudanças de língua em situações de entrevista com "alemães" no Brasil que remigraram para a Alemanha nacional-socialista no contexto da Campanha de Nacionalização brasileira e foram repatriados após a II Guerra Mundial. São levadas em consideração as condições de produção desses ricos relatos orais, assim como questôes sobre sua interpretação e tradução. A autora propõe uma análise transcultural dos relatos, considerando que esses migrantes viveram entre diferentes culturas e línguas. Reflete, ainda, sobre a influência de múltiplas migraçôes entre países e experiências de guerra na construção de identidades híbridas através da língua(gem).

Palavras-chave: migrações múltiplas, alemães no Brasil, mudança de língua, memória, identidade.

\title{
Language, memory and identity. Methodological considerations about life narratives of bilingual migrants
}

\begin{abstract}
This article discusses the use of different languages and their switch in Oral History interviews of bilingual "Germans" in Brazil who remigrated to Nazi Germany in the context of Brazilian Nationalization Campaign and were repatriated after WW II. Conditions of production of these rich oral sources, questions of interpretation and translation are taken in consideration. The author proposes an analysis in a transcultural manner, because these migrants lived between different cultures and languages. The article reflects on the influence of multiple migration and war experiences on the construction of hybrid identities through language.
\end{abstract}

Keywords: multiple migrations, German-Brazilians, language switch, memory, identity. 